\title{
The effect of corruption on carbon dioxide emissions and energy consumption in Tunisia
}

\author{
Habib Sekrafi \\ Department of Economics, Universite de Sousse, Sousse, Tunisia, and \\ Asma Sghaier \\ Department of Finance and Accounting, \\ Higher Institute of Management of Sousse, Monastir, Tunisia
}

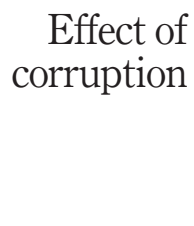

\begin{abstract}
Purpose - The purpose of this paper is to evaluate the impact of corruption on the environmental quality in Tunisia. Indeed, the post-revolution period is characterized by a remarkable increase in the rates of corruption.

Design/methodology/approach - The direct and indirect effects of control corruption on economic growth and $\mathrm{CO}_{2}$ emissions in Tunisia have been examined using the autoregressive distributed lag (ARDL) cointegration framework among corruption, growth and $\mathrm{CO}_{2}$ emissions.

Findings - Results substantiate a positive and significant relationship between control of corruption and economic growth, a negative and significant relationship between control of corruption and environmental quality $\left(\mathrm{CO}_{2}\right)$ and a negative and significant relationship between control of corruption and energy consumption. The findings suggest that while the control of corruption contributes to economic growth, its positive effect could be transposed indirectly via its impacts on environmental quality.

Originality/value - A strategy against corruption will reduce $\mathrm{CO}_{2}$ emissions; however, its positive effect on economic growth indirectly contributes to reverse this relationship.
\end{abstract}

Keywords Energy consumption, ARDL, Corruption, Tunisia, Carbon dioxide $\left(\mathrm{CO}_{2}\right)$

Paper type Research paper

\section{Introduction}

In recent years, an interesting research has shown significant economic implications of corruption. On the basis of cross-national data, corruption has affected a large variety of economic variables (Wei, 2000; Fisman and Svensson, 2000; Lambsdorff, 1999; Mauro, 1995; Guetat, 2006). The negative effect of corruption on prosperity has been examined by several papers (Mauro, 1995; Hall and Jones, 1999, and Kaufmann et al., 1999). In addition, theoretical analyses and case studies have suggested that corruption is an important source of environmental degradation by reducing the stringency of environmental regulations (Fredriksson et al., 2004; Damania et al., 2003; Lopez and Mitra, 2000) or the effectiveness with which environmental regulation is enforced (Hafner, 1998; Lippe, 1999), especially for

(C) Habib Sekrafi and Asma Sghaier. Published in the PSU Research Review: An International Journal. Published by Emerald Publishing Limited. This article is published under the Creative Commons Attribution (CC BY 4.0) licence. Anyone may reproduce, distribute, translate and create derivative works of this article (for both commercial and non-commercial purposes), subject to full attribution to the original publication and authors. The full terms of this licence may be seen at http:// creativecommons.org/licences/by/4.0/legalcode

JEL classification - O44, Q51, Q57

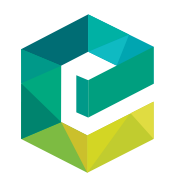

Received 3 November 2016 Revised 2 March 2017 Accepted 6 March 2017 
PRR

2,1

82

developing countries (Desai, 1998). However, the quantitative assessments of the environmental effects of corruption are very rare, which increase the uncertainty regarding the magnitude and significance of any such impact (Welsch, 2004). According to Grossman and Krueger (1995), there is a threshold effect of corruption on environment. In fact, corruption may lead to lower pollution at some income levels and to higher pollution at others.

The aim of this paper is to provide an examination of the corruption-environment link. It will quantify two distinct mechanisms through which corruption will influence pollution. The first mechanism of connection is the direct impact of corruption on environmental regulation and enforcement (Welsch, 2004). The second one is "indirect" through economic growth. This is possible due to a link between economic growth and pollution described by many studies. This literature shows the possibility of an inverted-U shaped relationship between per capital income and pollution, commonly known as an environmental Kuznets curve (EKC). However, at a certain level of economic maturity, this relationship[1] gets reversed. By influencing the per capital income, corruption will therefore indirectly affect pollution. The contribution of this paper is therefore to quantify both the direct and indirect effects of corruption on environment in Tunisia. No previous study has attempted to analyze how the level of corruption can affect environment in Tunisia.

Corruption is a global problem which reacts with force affecting all countries of the world and all sectors of activities. In particular, African countries are mostly characterized by weak institutions and poor governance (World Bank, 2010). Indeed, statistics on the Corruption Perceptions Index (CPI) indicate that more than two-thirds of African countries had a perception index below 3 in 2011, which implies that corruption is perceived as endemic (Transparency International index 2012). The publications of CPI between 2004 and 2011 show that an average of four to five African countries are among the ten countries perceived as most corrupted in the world. For Tunisia, the CPI rank declined rapidly to the 79th place in 2014, while it was 59th place in 2010. Also, according to a study by Global Financial Integrity (2011) cited in a recent report by the World Bank, corruption costs Tunisia more than 2 per cent of its GDP - its total cost is estimated at $\$ 1.2 \mathrm{bn}$ per year (or $\$ 110$ /capital) during the period 2000-2008. Based on a perception study in 2011, the Tunisian corporate governance central has sought to establish a barometer for measuring and monitoring the level of corruption. This work is conducted through a questionnaire of a sample of 250 citizens with the survey themes: the perception of corruption by sector, the degree of acceptability of behavior corruption, the different attitudes to corrupt practices, the assessment of government action to fight against corruption and measure the risk of corruption. Findings from this study indicate that Tunisia should face the problem of corruption because it is considered as the second problem after unemployment.

The very high level of corruption in Africa, particularly in Tunisia, coincides with poor performance in sustainable development. According to the Environmental Performance Index (EPI) 2010 (EPI, 2018), Tunisia is ranked in 74th out of the 163 countries of the world and 5 th in Africa, with a score of 60.6 out of 100. Thus, corruption affects environmental regulations by introducing a bias, not only in the adoption process but also in the implementation process and the application of these regulations (Welsch, 2004). In a country marked by high levels of corruption, polluters or the extractors of natural resources can escape environmental regulations by offering bribes to the administrative authorities responsible for environmental regulation, (Wilson and Damania, 2005; Fredriksson et al., 2004; Lopez and Mitra, 2000).

Also, corruption affects the environmental quality through the informal sector (Biswas et al., 2011). Indeed, strengthening the informal sector increases pollution levels and leads to 
environmental degradation (Blackman, 2000; Blackman and Bannister, 1998; Biller, 1994). The strict environmental regulations may encourage firms to migrate more toward the informal economy for maximizing their profit (Baksi and Bose, 2010; Chaudhuri and Mukhopadhyay, 2006). These findings are consistent with the current Tunisian economic situation. Indeed, according to the IMF, the share of the informal economy at the GDP level is about 34 per cent in Tunisia. Also, the World Bank estimates that more than 50 per cent of the Tunisian labor force is used in the informal sector which represents 38 per cent of the GDP (Directorate General of the Treasury, 2018). We can conclude that the share of the increasingly growing informal sector is one of the main factors of environmental degradation.

The remainder of the paper is organized as follows; Section 2 examines the previous largely theoretical literature about the relationship between corruption, economic growth and environment degradation; while Section 3 outlines the methodology and data using an empirical model. Section 4 analyzes the findings, and Section 5 provides conclusions and policy implications.

\section{Corruption, growth and environment: a literature review}

Corruption continues to be a serious concern across the globe (Goel and Nelson, 2010). Corruption is defined by Transparency International, which produces one of the most commonly used corruption indexes; as the abuse of uninterested power for private gain. It is also defined as an act in which public authorities use their power to obtain personal benefits by circumventing the rules of the game (Jain, 2001). Corruption is the misuse of public office for private gains (Bardhan, 1997), and its economy-wide effects are shown by Swaleheen (2011); Treisman (2000) and Damania et al. (2003). Stiglitz (2002) affirms that the "government is supposed to act in the interest of citizens, not to use its enormous power to benefit its leaders or special interests at the expense of the general public".

Reducing corruption and its effects requires an understanding of its causes (Dong et al., 2012). Thus, economic literature addresses the determinants of corruption (Ades and Di Tella, 1997, 1999; Del Monte and Papagni, 2007; Shleifer and Vishny, 1993). Treisman (2000) argues that the level of corruption depends on the balance between the costs associated with being corrupt and the benefit from it. The economic variables related to corruption determinants and its effects on economic growth are also analyzed (Guetat, 2006; Mauro, 1995, 1998). Wu et al. (2010) find that in low-income countries, corruption acts as an economic disincentive because it distorts the effect of public expenditure on economic growth. Salinas-Jiménez and Salinas-Jiménez (2007), analyzing corruption, productivity and economic growth in 22 OECD countries during the 1980-2000 period, show that corruption negatively influences the growth performance of advanced economies.

Fisman and Svensson (2000) develop a theory of environmental policy, taking into account corruption and political instability. According to them, corruption has a negative effect on the strictness of environmental regulations, but this effect fades away as political instability increases. The effects of corruption on the environment are shown by Wilson and Damania (2005), Damania et al. (2003), Desai (1998) and Cole (2007). Political instability may allow the lobby groups to bribe the government on the aspects of regulations or distort the regulations related to pollution control measures that may favor them. But, the government may not maintain its power sufficiently to implement the desirable regulations. Corruption affecting environmental issues is more frequent in developing countries with higher political instability and weaker institutions (Lopez and Mitra, 2000). 
PRR

2,1

84

According to Costantini and Monni (2008), the environmental quality is positively affected by the institutions' quality. Cole and Fredriksson (2009) conclude that countries with weak environmental institutions will attract an intensive pollution industry. Bernauer and Koubi (2009) show an empirical evidence of an independent positive effect of the democracy level on air quality.

Damania et al. (2003) point out that in developing countries corruption is the main factor affecting environmental degradation. Arrow et al. (1995) argue that in poor countries, material welfare is more important than environmental degradation. Desai (1998) finds empirical evidence for the effect of corruption on environmental degradation by examining ten developing countries.

Barbier et al. (2005) highlight that in Asia, South America and Africa, deforestation is a result of government's support to large-scale plantations, timber harvesting and cash crops. These policies are also responsible for the depletion of natural resources and loss of biodiversity.

Fredriksson et al. (2004) study the effect of corruption on energy policy. They reveal that the effect of corruption on the energy policy is identical to that on environmental policy. They prove that more corruption means less stringent pro-environment policies. Damania et al. (2003) investigate the interaction between corruption, trade and environmental policy. They conclude that more corruption leads to less environmental regulations, whereas more trade policy liberalization leads to more environmental regulations. According to Fredriksson (1999), open trade increases the incentives to put pressure on government's decisions on environmental policy. According to Welsch (2004) corruption affects pollution directly and indirectly.

\section{Analytical framework and methodology}

\subsection{Analytical framework}

The study is based on the conceptual framework of endogenous growth theory and the environmental Kuznets curve (EKC). The consideration of this double theoretical anchor can simultaneously identify the direct and indirect effects of corruption on the environmental quality. Corruption has a direct effect on the environmental quality by weakening environmental regulations and an indirect effect through economic growth channel (Welsch, 2004; Lopez and Mitra, 2000). Our study uses the methodology used by Cole (2007). To identify the different theoretical effects of corruption on the environment, we use the following functional forms:

$$
\begin{gathered}
G D P_{t}=f\left(E C_{t}, C O 2_{t}, C C_{t}, i n v_{t}\right) \\
C O 2_{t}=f\left(G D P_{t}, G D P_{t}^{2}, C C_{t}\right) \\
E C_{t}=f\left(G D P_{t}, C O 2_{t}, C C_{t}, P O P_{t}\right)
\end{gathered}
$$

GDP is the gross domestic product per capital. It is used as a proxy for economic growth. $\mathrm{CO} 2$ is emissions of carbon dioxide per capita and used as a proxy for environmental quality. $\mathrm{CC}$ is the level of the control corruption; the variables that define corruption are extracted from the World Bank "responsible use his position a public service to its own benefit." The CC index is a standardized continuous quantitative measure (centered and reduced variable), which varied between -2.5 (high level of 
corruption) and 2.5 (minimum level of corruption). The control of corruption captures perceptions of the extent to which public power is exercised for private gain, including both petty and grand forms of corruption, as well as "capture" of the state by elites and private interests. INV is investment ratio to GDP, EC is the energy use per capital and POP is the total population.

The annual data cover the period between 1984 and 2012. These data are collected from the WDI (2013) for GDP, energy consumption (EC), CO2 emissions (CO2), population (POP) and investment (INV). The level of the control corruption (CC) variable is extracted from WGI.

\subsection{Methodology}

Most studies of causal relationships for a time series emphasize vector autoregression (VAR) modeling to highlight the relationships between the variables studied. Also, the study of the existence of cointegration relation between these variables is based on the usual tests, namely, the Johansen test. However, the implementation of this method requires that the series be integrated in the same order. However, in most macroeconomic series, this condition is not verified (Nelson and Plosser, 1982). In response to this shortcoming, Pesaran et al. (2001) defined the autoregressive distributed lag (ARDL) approach, taking into account the shortcomings of the VAR model.

3.2.1 Unit root test. The previous hypothesis of the analysis of the model ARDL states that the variables may be either (I1) or (I0). To avoid erroneous results, we conducted unit root tests to verify that the series are not integrated of order two or more. To do this, our study has used three unit root tests. In addition to, the traditional Phillips-Perron (PP) and augmented Dickey-Fuller (ADF) tests, we have used the unit root test procedure developed by Zivot and Andrews (1992) who allow taking into account the breaks in the deterministic terms to test the stationarity of the variables. The main advantage of the Zivot-Andrews test is that the timing of the structural break is endogenously determined.

3.2.2. Bounds tests. To assess the impact of corruption on energy consumption and environmental quality in Tunisia, we rely on the ARDL model developed by Pesaran and Shin (1999). This model has been extended by Pesaran et al. (2001). The use of this model is justified by the fact that it takes into account both short- and long-term relationships of the tested variables. Also, the ARDL model allows estimating variables of different levels of integration [I(1) and I(0)]. According to Pesaran et al. (2001), the cointegration test is based on $F$-statistic. The Fisher statistic assumed that the coefficients in level variables are all equal to zero and under the alternative hypothesis that none of the null coefficients, which means no cointegration between the variables, are studied. Thus, to study the total effect of corruption on energy consumption and environmental quality, we use the representations ARDL of the equations (1), (2) and (3):

$$
\begin{aligned}
\Delta G D P_{t}= & \alpha_{0}+\alpha_{1} G D P_{t-1}+\alpha_{2} E C_{t-1}+\alpha_{3} C O 2_{t-1}+\alpha_{4} C C_{t-1} \\
& +\alpha_{5} I N V_{t-1}+\sum_{i=0}^{m} \beta_{1 i} \Delta G D P_{t-i}+\sum_{i=0}^{n} \beta_{2 i} \Delta E C_{t-i}+\sum_{i=0}^{p} \beta_{3 i} \Delta C O 2_{t-i} \\
& +\sum_{i=0}^{q} \beta_{4 i} \Delta C C_{t-i}+\sum_{i=0}^{l} \beta_{5 i} \Delta I N V_{t-i}+\varepsilon_{t}
\end{aligned}
$$


PRR

2,1

\section{6}

$$
\begin{aligned}
\Delta C O 2_{t}= & \alpha_{0}+\alpha_{1} C O 2_{t-1}+\alpha_{2} G D P_{t-1}+\alpha_{3} G D P_{t-1}^{2}+\alpha_{4} C C_{t-1}+\sum_{i=0}^{m} \beta_{1 i} \Delta C O 2_{t-i} \\
& +\sum_{i=0}^{n} \beta_{2 i} \Delta G D P_{t-i}+\sum_{i=0}^{p} \beta_{3 i} \Delta G D P_{t-i}^{2}++\sum_{i=0}^{q} \beta_{4 i} \Delta C C_{t-i}+\varepsilon_{t}
\end{aligned}
$$

$$
\begin{aligned}
\Delta E C_{t}= & \alpha_{0}+\alpha_{1} E C_{t-1}+\alpha_{2} G D P_{t-1}+\alpha_{3} C O 2_{t-1}+\alpha_{4} C C_{t-1}+\alpha_{5} P O P_{t-1}+\sum_{i=0}^{m} \beta_{1 i} \Delta E C_{t-i} \\
& +\sum_{i=0}^{n} \beta_{2 i} \Delta G D P_{t-i}+\sum_{i=0}^{p} \beta_{3 i} \Delta C O 2_{t-i}+\sum_{i=0}^{q} \beta_{4 i} \Delta C C_{t-i}+\sum_{i=0}^{l} \beta_{5 i} \Delta P O P_{t-i}+\varepsilon_{t}
\end{aligned}
$$

In the equations, $\Delta$ denotes the first difference operator; $\alpha_{0}$ represents the constant, and $\varepsilon_{\mathrm{t}}$ represents the error term. The coefficients of $\beta_{1}$ to $\beta_{5}$ illustrate the short-run dynamics in each function. Those associated with the $\alpha_{i}$ parameter, with $\mathrm{i} \neq 0$, represent the long-run dynamics of the respective models.

The bounds test is based on the Fisher test: the null hypothesis $(H O)$ warrants the absence of cointegration among the variables against alternative hypothesis $(H 1)$ which proved the existence of cointegration among variables: $H O: \alpha_{1}=\alpha_{2}=\alpha_{3}=\alpha_{4}=\alpha_{5}=0$ versus $H_{1}$ : $\alpha_{1} \neq$ $\alpha_{2} \neq \alpha_{3} \neq \alpha_{4} \neq \alpha_{5} \neq 0$. Pesaran suggest two sets of critical values for a given significance level. Assuming that all variables included in the ARDL model are integrated of order zero I (0), the first level is then calculated. The second level is calculated assuming that the variables are integrated of order one I(1). In case the computed $F$-statistics are above the higher critical bounds, the null hypothesis of no co-integration is rejected whether the series is $\mathrm{I}(0)$ or I(1), so co-integration is verified. In the opposite case where the computed $F$-statistic falls below the lower critical value, the null hypothesis cannot be rejected, indicating no co-integration. Finally, if the computed test statistics lie between the bounds, no conclusion can be made without calculating the integration order of the regressors.

3.2.3 Identifying the impact of corruption on pollution. The total effect of corruption on economic growth, environmental quality and energy consumption consists of two effects: a direct effect which reflects the degree of government regulation and an indirect effect through economic growth. These effects can be expressed as follows:

$$
\begin{gathered}
\frac{\partial Y}{\partial c c}+\frac{\partial Y}{\partial E} * \frac{\partial E}{\partial c c}+\frac{\partial Y}{\partial E C} * \frac{\partial E C}{\partial c c} \\
\frac{d E}{d c c}=\frac{\partial E}{\partial c c}+\frac{\partial E}{\partial Y} * \frac{\partial Y}{\partial c c} \\
\frac{\partial E C}{\partial c c}+\frac{\partial E C}{\partial E} * \frac{\partial E}{\partial c c}+\frac{\partial E C}{\partial Y} * \frac{\partial Y}{\partial c c}
\end{gathered}
$$

Where E, CC, EC and Y denote per capital pollution emissions, control of corruption, energy consumption and per capital income, respectively. 
Referring to equation (1), it should be noted that the inclusion of energy consumption and $\mathrm{CO} 2$ emissions terms implies that $\delta Y / \delta E$ is a function of the level of per capital emissions and $\delta Y / \delta E C$ is a function of the level of per capital energy use. In equation (2), it should be noted that the inclusion of quadratic income terms implies that $\delta E / \delta Y$ is a function of the level of PIB per capital income. Finally, in equation (3), it should be noted that the energy consumption is based on the variables according to GDP by capital and $\mathrm{CO} 2$ emissions. Therefore, they are the indirect effects as a whole.

\section{Results and discussion}

In this paper, we have used ADF, PP and Zivot-Andrews methods to investigate whether corruption, energy consumption, carbon emissions and economic growth in Tunisia are stationary from 1984 to 2012. The results of unit root tests are presented in Table I.

We have chosen the critical value level to be at 5 per cent. The results of $\mathrm{ADF}$ and $\mathrm{PP}$ in Table (I) indicate that all $t$-values of level analysis are more than the critical value at 5 per cent significance, which accepts null hypothesis and indicates the existence of a unit root value. However, all $t$-values of the first difference analysis are less than the critical value at 5 per cent significance level, which rejects null hypothesis and indicates the absence of the unit root value. The Zivot and Andrews (1992) test suggest that GDP, CO2, EC, GDP2, INV and DC variables are non-stationary in levels. The $t$-values of the level analysis are more than the critical value at 5 per cent significance, which accepts null hypothesis and indicates the existence of the unit root value. However, in the first difference analysis, all $t$-values are less than the critical value at the 5 per cent significance level, which rejects null hypothesis and indicates the absence of the unit root value. For the (POP) variable, the $t$-values are above the critical threshold value of 5 per cent which indicates the absence of the unit root value in Level $\mathrm{I}(0)$.

The Zivot and Andrews (1992) test provides mixed results for the integration order. Therefore, bounds tests are used to analyze the long-term relationship between corruption, energy consumption, economic growth and environmental quality. The bounds test for level relationships is presented in Table II.

The results of the bounds test in Table (II) indicate that the value of the $F$-statistic is more than the upper-bounds critical value at 5 per cent in the three studied models. Therefore, we can conclude the existence of long-run relationships between growth and other variables, the

\begin{tabular}{lccccrr}
\hline & \multicolumn{2}{c}{ ADF test } & \multicolumn{2}{c}{ PP test } & \multicolumn{2}{c}{ Zivot-Andrews } \\
Variables & In level & First difference & In level & First difference & In level & First difference \\
\hline GDP & 0.8970 & -5.240 & $0.974[1]$ & $-5.256[2]$ & $-3.8270(1989)$ & $-7.8580(1992)$ \\
CO2 & $-0.103[1]$ & -7.9490 & $-0.202[1]$ & $-7.910[1]$ & $-3.437[2](1996)$ & $-8.5470(1990)$ \\
EC & $-0.209[1]$ & -9.4040 & $-0.281[8]$ & $-8.721[2]$ & $-4.289[2](2005)$ & $-13.000(1991)$ \\
GDP2 & 1.0180 & -5.120 & $1.089[1]$ & $-5.136[2]$ & $-3.5290(1989)$ & $-7.6840(1992)$ \\
Inv & -1.5560 & -6.6070 & $-1.435[2]$ & $-6.727[2]$ & $-4.3060(2001)$ & $-7.0170(2006)$ \\
POP & $-1.004[2]$ & $-2.798[3]$ & $-1.004[3]$ & $-2.321[2]$ & $-6.758[2](2002)$ & \\
CC & -2.0550 & -4.920 & -2.0550 & $-4.939[4]$ & $-2.9050(2001)$ & $-4.5740(1999)$
\end{tabular}

Notes: SC is used to choose the number of optimal delays for the ADF tests, whereas "Bandwidth" is used for PP tests. The critical values related to ADF and PP tests were provided by MacKinnon (1996). The bracketed figures represent the delay levels based on the information criterion of Schwarz. Figures between square brackets represent Newey-West bandwidth's automatic selection using the Bartlett kernel. Note that only the constant is included in tests. [.] Numbers of lag lengths. Numbers in brackets are the break year

Table I.

Unit root tests 
PRR

2,1

long-run relationships between $\mathrm{CO} 2$ emissions and other variables and the long-run relationships between energy consumption and other variables. The obtained results from the bounds test are confirmed by the error correction model in each equation. The $\operatorname{ECM}(-1)$ terms is negatively significant at the 5 per cent level. The null hypothesis of no cointegration is rejected.

After confirming the existence of a long-run relationship between the variables of the three models, we proceed in a second step to estimate the long- and short-run effects between endogenous and exogenous variables in Tunisia. The long-run results are present in Table III.

The results of Table III allow us to identify the nature of the relationship between our variables. Thus, according to the results of the equation of the growth, we note that the consumption of energy positively and significantly affects the economic growth: any increase in a point of GDP is accompanied by an increase in the amounts of energy used by 1.6 points. The results show a strong positive correlation between the growth level and the energy consumption in Tunisia. In fact, Tunisia is one of the developing countries where any increase in the level of GDP causes the consumption of additional quantities of energy. Thus, the adoption of a conservation energy policy in the region must take into account the risks of a negative impact in the short and long term. Also, the coefficient associated with $\mathrm{CO} 2$ is significantly negative in the long term: the increase in income levels is accompanied by a reduction in the quantities of pollutants. This result confirms that Tunisia will reach, in the long term, the threshold level of income which will allow it to reverse the relationship between GDP and emissions of $\mathrm{CO} 2$. In fact this result can be justified by the strategies pursued by the Tunisian Republic for the fight against climate change. Tunisia has implemented several programs since the creation of the National Sanitation Board, which

\begin{tabular}{lccccl}
\hline & & \multicolumn{2}{c}{ ecm $(-1)$} & & \\
Dependent variable & Lag selection & coef & $t$-value & $F$-statistic & Decision \\
\hline F(GDPECC, CO2, CC, INV) & $(2,3,3,3,3)$ & -1.1651 & -4.7975 & 4.643464 & co integration \\
F(CO2\GDP, GDP2, CC) & $(0,3,2,2)$ & -1.1381 & -5.9995 & 4.123260 & co integration \\
F(ECIGDP, CO2,CC, POP) & $(3,3,2,3,3)$ & -3.3148 & -7.8990 & 8.145328 & co integration
\end{tabular}

Table II. $\quad \mathrm{k}=3$

The bounds test for level relationships

$\mathrm{k}=4$
Lower-bound critical value at $5 \%$ 2.79 2.56
Upper-bound critical value at $5 \%$ 3.67

3.49

Notes: Lower- and upper-bound critical values are taken from Pesaran et al. (2001); Table CI(ii) Case II 
enabled it to reach a connection rate to the public sewerage network of 88.7 per cent. Management of household waste And assimilated, through the establishment of a network of 10 controlled landfills and 48 transfer operations in operation, and 10 other controlled landfills and 60 transfer centers under way, increasing the rate of household waste management In controlled landfills from 45per cent in 2007 to 93 per cent in 2011.

The results equations (1) prove that the coefficient associated with the variable control of corruption is positive and significant. Thus, any increase in the level of control of corruption stimulates economic growth. An improvement in the level of control of the corruption by a point increases the level of GDP by 0.196 point. We can conclude that corruption negatively affects the growth and improvement in the control level of corruption fact reduces this negative effect. This is explained by the fact that corruption reduces the investment, affects the public expenditure and reduces growth. Our results are consistent with the empirical literature (Delgado et al., 2014, Acemoglu et al., 2003; Mauro, 1995) .

In equation (2), we have proved, as in the first finding, that the environmental Kuznets curve is well justified in its quadratic form and it takes the form of a reverse U. In fact, the coefficient associated with the variable GDP is negatively significant, whereas the coefficient associated with the GDP2 is positive and significant. Indeed, the long-run elasticity of CO2 emissions with respect to income is $y=0,1317$ GDP-0,4427.

In the second finding, the results indicate a significant negative relationship between the control of corruption and the quantities of $\mathrm{CO} 2$ in the atmosphere. Any increase in the level of control of corruption by a point reduces the quantities of $\mathrm{CO} 2$ by 0.0808 point. This is explained by the fact that the increase in the level of control of corruption, expressed by a regulatory policy and imposition of the tax laws, obliges the polluters to reduce their emissions and meet the standards of the country. In other words, corruption has the effect of weakening the environmental regulations by introducing a bias, not only in the adoption process but also in the process of implementation or implementation of these regulations (Wilson and Damania, 2005; Fredriksson et al., 2004). In the case of Tunisia, the sectors, structures or services (the security services, the customs) are considered to be the most affected by corruption.

From the results of equations (3), we note that the coefficient associated with the variable GDP is significantly positive. Any development in the level of GDP by a point increases the quantities of energy used for the loan by 0.529 point. In effect, the Tunisian economy is in its transitional phase where the increase in GDP encourages firms to use more luxury goods (air conditioning, electric heating, cars). Besides, the number of vehicles in Tunisia was estimated to reach 1.8 million by 2015 , with an increase of 70,000 cars per year [the technical agency of Land Transport (ATTT)].

The variable control of corruption admits a negative and significant coefficient in 1 per cent. Any increase in the level of control of corruption by a point reduces the quantities of energy used by 0.075 point. This is explained by the growing illegal demand for gasoline coming from Libya. The informal sector is the third problem from which Tunisian companies complain. While it is 38 per cent in the region of the European Bank for Reconstruction and Development, London, and 40.2 per cent in the south and east of the Mediterranean, the rate of businesses which are in competition with the informal sector is 45.2 per cent in Tunisia. The magnitude of this phenomenon is far from decreasing with time; quite the contrary, it is increasing as the share of the informal economy in the GDP increased from 30 per cent in 2010 to 38 per cent in 2013.

The regression for the underlying ARDL equation fits very well, and the two models [equations (1) and (2)] are significant at the 1 per cent level. In fact, as shown in Table IV, 
PRR

2,1

90

none of the estimated models have serial correlation, heteroscedasticity, non-normality, gold functional form.

In addition to the diagnostic tests, the stability tests of co-integrated parameters (CUSUM and CUSUMQ) confirm a stable long-run equilibrium. These tests for parameter of stability based on the residuals recursive regression have been developed by Pesaran and Shin (1999).

In a final step, we determine the total effect of corruption on the quality of the environment. Referring to equations (7), (8) and (9), the calculations of our results are presented in Table V.

The results indicate that the control of corruption admits a direct positive effect on growth. The improvement of the regulatory system stimulates the growth in a direct way. However, our results indicate a total negative effect. The indirect effects through the consumption of energy and the quality of the environment dominate the direct effect. This finding is explained by the more or less important weight in the informal sector in Tunisia. In effect, a loan of 40 per cent of GDP is of the provenance of the informal sector. As well, any increase in the regulatory system is going to disrupt the share of GDP from the informal sector. Also, the dominance of indirect effects can be evidence for the hypothesis of the Le Havre pollution. The majority of investors install their project in developing countries, Tunisia is an example, as these countries are characterized by a tax system more or less fragile, enabling them to issue additional quantities of pollutant without anyone going against it.

The results also indicate that the control of corruption admits a direct negative effect on the quality of the environment. Any increase in the level of control is a decrease in the quantities of $\mathrm{CO} 2$ emitted in the atmosphere and all the increase in the level of corruption is an increase in the quantities of the pollutant. In other words, corruption affects directly the quality of the environment in Tunisia. In addition, the indirect effect of the control of corruption on the rates of emission of $\mathrm{CO} 2$ per head is positive. An increase in the level of control of corruption by 1 per cent leads to an increase in the rate of emissions of $\mathrm{CO} 2$ per head of 0.11355 per cent via the economic growth. Indeed, improving the level of real GDP/ Head, Control of Corruption contributes to the increase of the rate of $\mathrm{CO} 2$ emissions per head. The indirect effect of the control of corruption is therefore greater than the absolute value of the direct effect. Therefore, the net effect of the control of corruption on the quality of the environment is positive in Tunisia. An increase in the level of control of corruption of 1 per cent increases emissions of $\mathrm{CO} 2$ by 0.0327 per cent. Corruption will affect the quality of the environment in Tunisia, more via the evolution of real GDP/head than by the weakening of environmental regulations. This result is explained by the non-political stability of the country; any increase in the control and environmental regulation encourages the polluters

\begin{tabular}{lccc}
\hline Tests & $\begin{array}{c}\text { F(GDPIEC, CO2, CC, INV) } \\
\text { LM Version }\end{array}$ & $\begin{array}{c}\text { F(CO2)GDP, GDP2, CC) } \\
\text { LM Version }\end{array}$ & $\begin{array}{c}\text { F(ECIGDP, CO2, CC, POP) } \\
\text { LM Version }\end{array}$ \\
\hline Serial correlation $^{\mathrm{a}}$ & $1.5181[0.218]$ & $0.62585[0.429]$ & $9.4127[0.002]$ \\
Heteroscedasticity $^{\mathrm{b}}$ & $0.46259[0.496]$ & $2.1269[0.145]$ & $8.6145[0.003]$ \\
Normality $^{\mathrm{c}}$ & $0.42701[0.808]$ & $0.16184[0.922]$ & $1.2189[0.544]$ \\
Functional form $^{\mathrm{d}}$ & $0.49616[0.481]$ & $0.0086605[0.926]$ & $0.39642[0.529]$ \\
CUSUM $^{\text {CUSUMQ }}$ & Stable & Stable & Stable \\
CUSU & Stable & Stable & Stable
\end{tabular}

Table IV.

Diagnostic test results
Notes: ${ }^{a}$ The Breusch-Godfrey LM test statistic for no serial correlation; ${ }^{b}$ the White test statistic for homoscedasticity; ' the Jarque-Bera statistic for normality; ${ }^{d}$ the Ramsey Reset test statistic for regression specification error 


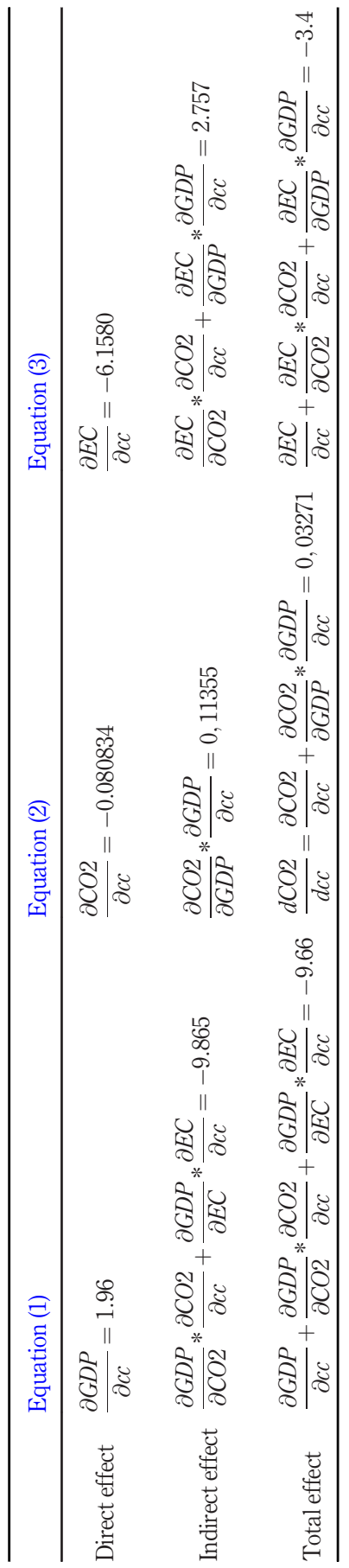

Effect of corruption

Table V. Decomposing the impact of corruption on pollution, growth and energy 
PRR

2,1

to migrate more toward the informal economy (Baksi and Bose, 2010). This result shows quite simply that the relative effect of growth on the quality of the environment is higher. As well, as Perkings (2003) indicates, the depth and the main gap should take care of the environmental experience acquired from developed countries through the transfer of technology “own”.

\section{Conclusion and policy implications}

The empirical analysis of the relationship between corruption, growth and environment has not been studied in the case of Tunisia. The results obtained by the study of this relationship allow us to define the economic and environmental policy which is appropriate for the improvement of human well-being. In this study, we have analyzed empirically the long-term relationship between corruption, economic growth and the quality of the environment. The justification of this research is that the economic growth and the quality of the environment are likely to be affected by the level of control of corruption.

The results of this study show the existence of a long-term relationship between economic growth, corruption, consumption of energy and quality of environment. The test statistics of bounds and the signs associated with the ECM confirm this finding. To complement the results of the analysis of cointegration, we analyze the long-term relationship between the variables through the ARDL model. The results prove that corruption negatively affects the economic growth in the long term. The degradation in the control of corruption by 1 per cent reduces the economic growth by 0.196 per cent. This result seems to be in conformity with the economic theory (Popova and Podolyakina, 2014). Besides, corruption has a direct positive effect on emissions of $\mathrm{CO} 2$ and the consumption of energy. Any degradation in the environmental regulation encourages the polluters to issue in advantage of additional quantities of pollutant and to extract quantities of more and more enormous natural resources.

Aside from these direct effects, corruption has also been estimated to have indirect effects on the growth and the quality of the environment. The results show that the indirect effect of corruption (control of corruption) on economic growth is positive (negative). The increase in the level of control of corruption (decrease of corruption) reduces the level of GDP through the reduction of the informal sector. The results show that the indirect effect of corruption environmental on emissions of $\mathrm{CO} 2$ is negative. The improvement in the level of control of corruption increases the quantities of pollutant via the channel growth. In effect, the improvement in the control of corruption increases the level of GDP which itself increases emissions of $\mathrm{CO} 2$. The relationship between growth and emissions is increasing.

The conclusion drawn from the sum of the two effects is that corruption has a total positive effect on economic growth and a total negative impact on the quality of the environment. This result seems to justify the economic theory (Cole, 2007) which paradoxically encourages the State to take into account important policy implications that can be presented as: the Tunisian authorities must implement a policy to reduce the share of the informal sector. To lower the levels of informal employment, an important involvement policy should take into consideration methods to make work in the formal sector more attractive (Abid and Ben Salha, 2013). The public authorities need to simplify administrative procedures, such as the registration of businesses. The State must set off regulatory instructions to preserve the quality of the environment. These instructions can be in the form of standards of emissions: use of solar heaters and the fixassions of quottât of emissions for the industry; technical standard: installing filters for the most polluting plants. Thus, the Tunisian Fund Anti-Pollution (FODEP 1995) provides grants to companies that seek to reduce or eliminate pollution. 
1. For more details see Cropper and Griffiths (1994), Grossman and Krueger (1995), Hettige and al. (1992), Martinez-Zarzoso and Bengochea-Morancho (2004), Selden and Song (1995). Recently, the EKC has been approved by others namely Lean and Smyth (2010); Ozturk and Acaravci (2010); Pao and Tsai (2010); Pao and al. (2011); Wang (2012), Song and al. (2008), Jalil and Mahmoud (2009), Shiyi (2009), Alam and al. (2012), Fodha and Zaghdoud. (2010).

\section{References}

Abid, M. and Ben Salha, O. (2013), "The informal economy in Tunisia: measurement and linkage with the formal economy", International Journal of Economics and Business Research, Vol. 6 No. 2, pp. 194-209.

Acemoglu, D., Johnson, S., Robinson, J.A. and Thaicharoen, Y. (2003), "Institutional causes, macroeconomic symptoms: volatility, crises and growth", Journal of Monetary Economics, Vol. 50 No. 1, pp. 49-123.

Ades, A.F. and Di Tella, R. (1997), "National champions and corruption: some unpleasant interventionist arithmetic", The Economic Journal, Vol. 107 No. 443, pp. 1023-1042.

Ades, A.F. and Di Tella, R. (1999), "Rents, competition, and corruption", American Economic Review, Vol. 89 No. 4, pp. 982-993.

Arrow, K., Bolin, B., Costanza, R., Dasgupta, P., Folke, C., Holling, C.S., Jansson, B.W., Levin, S., Mailer, K.G., Perrings, C. and Pimentel, D. (1995), "Economic growth, carrying capacity, and the environment”, Science (New York, N.Y.), Vol. 268 No. 5210, pp. 520-521.

Baksi, S. and Bose, P. (2010), "Environmental Regulation in the Presence of an Informal Sector", Working Paper No 2010-03, Department of Economics, The University of Winnipeg, Winnipeg.

Barbier, E., Damania, R. and Leonard, D. (2005), “Corruption, trade and resource conversion”, Journal of Environmental Economics and Management, Vol. 50 No. 2, pp. 276-299.

Bardhan, P. (1997), "Corruption and development: a review of issues", Journal of Economic Literature, Vol. 35 No. 3, pp. 1320-1346.

Bernauer, T. and Koubi, V. (2009), "Effects of political institutions on air quality", Ecological Economics, Vol. 68 No. 5, pp. 1355-1365.

Biller, D. (1994), "Informal, Gold Mining and Mercury Pollution in Brazil", Policy Research Working Paper 1304, The World Bank, Washington, DC.

Biswas, A.K., Farzanegan, M.R. and Thum, M. (2011), "Pollution, Shadow Economy and Corruption: Theory and Evidence", CESifo Working Paper N ${ }^{\circ} 3630$, Category 9: Resource and Environment Economics.

Blackman, A. (2000), "Informal sector pollution control: What policy option do we have?", World Development, Vol. 28, pp. 2067-2082.

Blackman, A. and Bannister, G. (1998), "Community pressure and clean technology in the informal sector: an econometric analysis of the adoption of propane by traditional mexican brickmakers", Journal of Environmental Economics and Management, Vol. 35, pp. 1-21.

Chaudhuri, S. and Mukhopadhyay, U. (2006), "Pollution and informal sector: a theoretical analysis", Journal of Economic Integration, Vol. 21, pp. 363-378.

Cole, M.A. (2007), "Corruption, income and the environment: an empirical analysis", Ecological Economics, Vol. 62 No. 3-4, pp. 637-647.

Cole, M.A. and Fredriksson, P.G. (2009), "Institutionalized pollution havens", Ecological Economics, Vol. 68 No. 4, pp. 925-1274.

Costantini, V. and Monni, S. (2008), "Environment, human development, and economic development", Ecological Economics, Vol. 64 No. 4, pp. 867-880. 
PRR

2,1

Cropper, M. and Griffiths, C. (1994), "The interaction of population growth and environmental quality", American Economic Review, Vol. 84 No. 2, pp. 250-254.

Damania, R., Fredriksson, P.G. and List, J.A. (2003), "Trade liberalization, corruption, and environmental policy formation: theory and evidence", Journal of Environmental Economics and Management, Vol. 46 No. 3, pp. 490-512.

Del Monte, A. and Papagni, E. (2007), "The determinants of corruption in Italy: Regional panel data analysis”, European Journal of Political Economy, Vol. 23 No. 2, pp. 379-396.

Delgado, M.S., McCloud, N. and Kumbhakar, S.C. (2014), "A generalized empirical model of corruption, foreign direct investment and growth”, Journal of Macroeconomics, Vol. 42 No. 1, pp. 298-316.

Desai, U. (Ed.) (1998), Ecological Policy and Politics in Developing Countries: Growth, Democracy and Environment, State University of New York Press, Albany.

Dong, B., Dulleck, U. and Torgler, B. (2012), “Conditional corruption”, Journal of Economic Psychology, Vol. 33 No. 3, pp. 609-627.

Environmental Performance Index (2018), "EPI publié par le Yale Center for Environmental Law and Policy”, available at: https:/epi.envirocenter.yale.edu/downloads/epi2018policymakerssummaryv01. pdf

Fisman, R. and Svensson, J. (2000), "Are corruption and taxation really harmful to growth? Firm level evidence”, World Bank Policy Research Working Paper Series, Vol. 2485.

Fredriksson, P. (1999), "The political economy of trade liberalization and environmental policy", Southern Economic Journal, Vol. 65 No. 3, pp. 513-525.

Fredriksson, P.G., Vollebergh, H. and Dijkgraaf, E. (2004), "Corruption and energy efficiency in OECD countries: theory and evidence", Journal of Environmental Economics and Management, Vol. 47 No. 2, pp. 207-231.

Global Financial Integrity (GFI) (2011), Illicit Financial Flows from Developing Countries: 2000-2009, GFI, Washington, DC, available at: www.gfintegrity.org/wp-content/uploads/ 2011/12/GFI_2010_IFF_Update_Report-Web.pdf

Goel, R.K. and Nelson, M.A. (2010), “Government Fragmentation versus Fiscal Decentralization and Corruption”, Public Choice, forthcoming.

Grossman, G.M. and Krueger, A.B. (1995), "Economic growth and the environment", The Quarterly Journal of Economics, Vol. 110 No. 2, pp. 353-377.

Guetat, I. (2006), "The effects of corruption on growth performance of the MENA countries", Journal of Economics \& Finance, Vol. 30 No. 2, pp. 208-221.

Hafner, C.M. (1998), "Structural analysis of portfolio risk using beta impulse response functions", Journal of Applied Econometrics, Vol, 52 No. 3, pp. 336-355.

Hall, R.E. and Jones, C.I. (1999), "Why do some countries produce so much more output per worker than others?”, Quarterly Journal of Economics, Vol. 114 No. 1, pp. 83-116.

Jain, A.K. (2001), “Corruption: a review”, Journal of Economic Surveys, Vol. 15 No. 1, pp. 71-121.

Kaufmann, D., Kraay, A. and Zoido-Lobaton, P. (1999), "Governance matters. World BankPolicy Research Working Paper No. 2196”. The World Bank, Washington, DC.

Lambsdorff, G.J. (1999). Corruption in empirical research: a review". Transparency International Working Paper Transparency International.

Lippe, M. (1999), "Corruption and Environment at the Local Level", Transparency International Working Paper, available at: www.transparency.org/documents/work-papers

Lopez, R. and Mitra, S. (2000), "Corruption, pollution and the environmental kuznets curve”, Journal of Environmental Economics and Management, Vol. 40 No. 2, pp. 137-150.

MacKinnon, J.G. (1996), "Numerical distribution functions for unit root and cointegration tests", Journal of Applied Econometrics, Vol. 11 No. 6, pp. 601-618. 
Martinez-Zarzoso, I. and Bengochea-Morancho, A. (2004), "Pooled mean group estimation of an environmental Kuznets curve for CO2”, Economics Letters, Vol. 82 No. 1, pp. 121-126.

Mauro, P. (1995), “Corruption and growth”, Quarterly Journal of Economics, Vol. 60 No. 3, pp. 681-712.

Mauro, P. (1998), "Corruption and the composition of government expenditure", Journal of Public Economics, Vol. 69 No. 2, pp. 263-279.

Nelson, C.R. and Plosser, C.I. (1982), "Trends and random walks in macroeconmic time series: some evidence and implications", Journal of Monetary Economics, Vol. 10 No. 2, pp. 139-162.

Pesaran, M.H. and Shin, Y. (1999), "An autoregressive distributed lag modelling approach to cointegration analysis", in Strom, S. (Ed.), Econometrics and Economic Theory in the 20th Century: The Ragnar Frisch Centennial Symposium, Cambridge University Press, Cambridge.

Pesaran, M.H., Shin, Y. and Smith, R.J. (2001), "Bounds testing approaches to the analysis of level relationships", Journal of Applied Econometrics, Vol. 16 No. 3, pp. 289-326.

Perkings, R. (2003), "Environmental leapfrogging in developing countries: a critical assessment and reconstruction", Natural Resources Forum, Vol. 27 No. 3, pp. 177-188.

Popova, Y. and Podolyakina, N. (2014), "Pervasive impact of corruption on social system and economic growth”, Social and Behavioral Sciences, Vol. 110, pp. $727-737$.

Salinas-Jiménez, M. and Salinas-Jiménez, J. (2007), “Corruption, efficiency and productivity in OECD countries”, Journal of Policy Modeling, Vol. 29 No. 6, pp. 903-915.

Shleifer, A. and Vishny, R.W. (1993), “Corruption”, The Quarterly Journal of Economics, Vol. 108, pp. 599-617.

Stiglitz, J. (2002), La Grande Désillusion, Fayard, Paris.

Swaleheen, M. (2011), "Economic growth with endogenous corruption: an empirical study", Public Choice, Vol. 146 Nos 1/2, pp. 23-41.

Treisman, D. (2000), "The causes of corruption: a cross-national study", Journal of Public Economics, Vol. 76 No. 3, pp. 399-457.

Wei, S.J. (2000), "Local corruption and global Capital flows", Brookings Papers on Economic Activity, Vol. 2000 No. 2, pp. 303-346.

Welsch, H. (2004), "Corruption, growth and the environment", Environment and Development Economics, Vol. 9 No. 5.

Wilson, J.K. and Damania, R. (2005), "Corruption, Political Competition and Environmental Policy", School of Economics Working Paper 03-9, University of Adelaïde, Adelaïde.

Wu, S.Y., Tang, J.H. and Lin, E. (2010), "The impact of government expenditure on economic growth: How sensitive to the level of development", Journal of Policy Modeling, Vol. 32 No. 6, pp. 804-817.

Zivot, E. and Andrews, D.W.K. (1992), "Further evidence on the great crash, the oil-price shock, and the unit-root hypothesis", Journal of Business \& Economic Statistics, Vol. 10 No. 3, pp. 251-270.

\section{Further reading}

Étude du Centre Tunisien de Gouvernance des entreprises - IACE (2011), "Indice de perception de la corruption par les citoyens".

\section{Corresponding author}

Asma Sghaier can be contacted at: asma_sghaier1983@yahoo.fr

For instructions on how to order reprints of this article, please visit our website:

www.emeraldgrouppublishing.com/licensing/reprints.htm

Or contact us for further details: permissions@emeraldinsight.com 